\title{
Surgical Margin Cannot be Assessed
}

National Cancer Institute

\section{Source}

National Cancer Institute. Surgical Margin Cannot be Assessed. NCI Thesaurus. Code C160719.

The determination of the presence of actual or potential neoplastic tissue which has been left outside the boundary of a resected specimen within the patient cannot be assessed. 